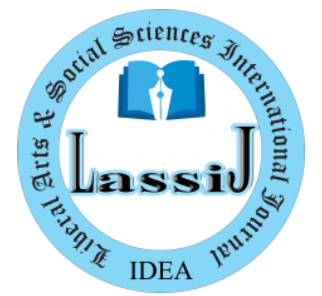

ISSN: 2664-8148 (Online)

Liberal Arts and Social Sciences

International Journal (LASSIJ)

https: / / doi.org/10.47264/idea.lassij/ 1.2.5

Vol. 1, No. 2, (July-December) 2017, 43-49

https://www.ideapublishers.org/lassij

\title{
The Problem of Post 9/11 Representation in Sikandar: A Postcolonial Perspective
}

\author{
Bakht Rahman ${ }^{1 *}$, Muhammad Arif $^{2}$ and Ansar Mehmood ${ }^{3}$
}

1. Department of English Language and Literature, Ghulam Ishaq Khan Institute of Technology, Swabi Pakistan.

2. Department of English Language and Literature, National University of Modern Languages (NUML), Islamabad Pakistan.

3. Department of English Language and Literature, The University of Lahore, Sargodha Campus, Sargodha Pakistan.

\begin{abstract}
The issue of representation has always been a concern in postcolonial discourse. It is the result of colonialism. Earlier, it was the physical domination of the West and it ruled over their colonies in various parts of the world like the Caribbean, and South Asia. Currently, it is cultural and imperialistic domination by the same powers and of the same territories. The basic concern of these western powers is that the colonized cannot represent themselves since they are inferior, uncivilized, barbaric, and illiterate and so many other terms are used for their disposition and particularly after the catastrophic incident of 9/11. This paper investigates the issue of representation in Sikanadar, a novel by $\mathbf{M}$ Salahuddin Khan where he confronts, although in soft language, this European/Western stance, and stresses on the importance of mutual respect and dignity and love for humanity. This is a qualitative research where the researcher has used interpretation and textual analysis through the lens of postcolonialism. It has used an eclectic framework by combining both Edward Sarian and Bhabha concepts of colonialism.
\end{abstract}

Keywords: Representation, Postcolonialism, Marginalization, Culture, Humanity

\section{Introduction}

Although Pakistan got independence in 1947, yet the cultural and socio-economic and political set up stays the same as in the pre-independence period. Culture is normally considered to be the backbone of any society; hence, writers cannot escape this aspect of their roots. Edward Said, also, highlights that 'every writer is a cultural product.' It is in this context that I have selected Sikandar to:(a) explore and analyse to what extent the author has been influenced by his cultural roots, (b) how he shows his displeasure/discontent with the empire, and (c) how and why he has tried to decolonize the mentality of his readers? Pakistani writers have responded to this phenomenon in creative writing and, particularly in fiction. However, it is important to critically investigate and acknowledge the contribution made by the Pakistani writers at both national and international 
horizons. Writers from other South Asian countries are already in the limelight, but Pakistani authors have been relegated to the background due to certain reasons. This study is an endeavour to critically evaluate Sikandar by M. Salahuddin Khan in the context of postcolonialism.

\section{Review of Literature}

'Postcolonial' has been defined in diverse ways by theorists and scholars. The critics and historians have used the term since the Second World War. Postcolonial, to Ashcroft et al., (1998), had a chronological interpretation which demarcates and portrays the post-independence period. However, the term, since the 1970s, is used by literary scholars and critics to investigate diverse cultural impacts of colonization and thereby it signifies the linguistic, political, and cultural experiences of those countries which were formerly European colonies. Therefore, the term has been used in a wide and multiple perspectives in the modern times. It includes, to Ashcraft et al. (1998) the study and analysis of European territorial subjugation, different organizations/institutions of colonialism, the discursive operations of the empire, the subtleties of subject edifice in colonial discourse as a text, and the resistance of the colonized in these discourses. Most importantly, the reaction to these 'incursions' and their counterpart colonial legacies in both pre and post-colonial regimes and territories with a strong concentration on their cultural contribution in politics, history, and literature which question the effects of colonialism is important in the context of postcolonial discourse.

Post-colonialism is, therefore, associated, now, with history, politics, sociology, and literature. In the economic analysis, these disciplines continue to deal with the impact of European imperialism on their colonies and its ramification in the modern times. Edward Said's Orientalism, in this regard, tries to express the complex relationship between the West and the East whereby he highlights the binary connection of structure of colonialism along with the depiction of a dominant imperial centre and a colonial periphery. He tries to explore how this hegemonic relationship and practices of the past are replicated in the modern times and how these colonizers are producing and manipulating knowledge. Said examines this hegemonic phenomenon in terms of binary relationship of 'Us' and 'Them' where the Occident is dominant, and the Orient is inferior. The socio-economic relationship between the colonizers and the colonized creates cultural perceptions of the 'Other.'

Said's framework of 'Self' and 'Other' becomes important since it gives an opportunity to analyse the western approach of the 'other' as their methods of assessment are different. The 'rational West' and the 'irrational Other' help the West to construct a European identity which is superior to the colonized one. This sense of superiority provides them with a pretext to colonize the Muslim and Arab world. As a result, this 'Us versus Them' paradigm empowered the West to depict the Orient as primitive, inferior, regressive, and irrational while, the West, on the other hand, as modern, superior, progressive and rational which is in a sharp contrast of the Oriental Other. Therefore, this western scholarship of the Orient/Other transforms to power structure of colonialism and imperialism. Here, at this very point, the relationship of the 'Self' and the 'Other' becomes the relationship of 'power, of domination, of varying degree of complex hegemony' (Said, 1978). 
As a theory, post colonialism plays a significant role in digging out the implicit messages contained in the works of writers who are against the colonial role in the world in general and in the subcontinent. It not only focuses on the subjugation of different countries but also on the injustices conducted in these countries on the name of good governance and rule of law. The colonial masters were not interested in the development and raising of the living standards of the people in the colonized territories, rather, they were primarily interested in the manipulation of resources and wealth in their respective colonies. This resulted in seriously poor and dilapidated economic and political conditions.

In this scenario, post-colonialism becomes an important framework to investigate the representational issues in the region. It was a kind of a pretext for the colonizers that since the people in this region are uncivilized and unable to represent themselves, it is their moral duty to make them civilized. In other word, it was a barbaric land with barbaric inhabitants. For this purpose, they ruled half of the world. As a result, in every field of life of these nations whether it is social, cultural, political, or economic, we can see the impact of this domination and control. Currently, colonialism is not physical rather it has become imperialistic as Marx (1992) believes that now colonialism is a form of international capitalism, focusing to grape capital of the world as their colonial regimes are in pursuit of their aims. Conrad (1983) depicts that colonialism is an international dissemination of capital. Moreover, colonialism today is beyond physical subjugation; it has now become capitalist and cultural subjugation as Jakub (2013) opines, 'colonialism and imperialism may be perceived as extraordinarily complex phenomena that influence not only the political or economic structure of a country but also, in the extreme case, eating habits (the global expansion of companies such as McDonalds, or KFC can in some aspects be seen as an act of cultural imperialism)'.

Colonialism has paved the way for post colonialism to bridge the gap between the East and the West. Now, through post colonialism, at least the people in the former colonies are conveying their feelings, emotions, messages and above all their concerns to the West by the appropriation of language. Appropriation is a key term since it is the device through which the writers from the East are talking to their western counterparts in their own native language. It is a process by which the language is made to bear the burden of one's own cultural experience or it describes the procedure and process of English adaptation itself (Ashcraft et al, 2007). The term appropriation is not restricted to language only. It goes forward to cultural appropriation and adaptations in terms of lifestyle as well. Adaptation of culture is defined (N. A, 2011) as, 'cultural appropriation is the adoption or the, of icons, rituals, aesthetic standards, and behaviour from one culture or subculture by another".

In contrast, abrogation is the total opposite of appropriation as it is the negation/rejection of the standardized language, used by the colonial masters. It is not only limited to the rejection of the language but the rejection of the culture, e.g., Western culture. Ashcroft et al (2007) defines abrogation as it is used to reject the language of the colonizers, which is actual sense the rejection of standard language. In post-colonial literature abrogation is found with the rejection of standard language. Closely related to appropriation is the concept of mimicry or imitation of the colonizers. Bhabha (1994) defines the term by saying, 'colonized are copying or imitating the behaviour, 
cultures, manners, way of dealing of colonizers, and consist of both menace and mockery. In addition, it resembles mockery and in certain value to menace." He explains the concept of stereotypes through its ambivalent nature, 'forms of knowledge and identification that vacillates between what is always 'in place' already known, and something that must be anxiously repeated.' Bhabha is, therefore, very pungent in his criticism of the colonizers who are die heartedly trying to portray the colonized as the "other."

In this context, stereotyping is an oversimplification of manipulated evidence which in real sense is a false representation of a certain truth. It is, according to Bhabha (1994) is fixated and arrested form of representation which in actual sense becomes a misrepresentation since it denies the existing realities and truths. Therefore, this act of stereotyping becomes imperative in the analysis of diverse cultures for both the colonizers and the colonized. The west has created this concept of 'otherness,' and therefore it is purely a European phenomenon. Since the colonizers are considering themselves as civilized, the colonized, because of this assumption, are, 'threatened by the differences of race, colour and culture.' According to Ashcroft et al (2007), it is the Western culture which stimulates or encourages the colonized to mimic the colonial subject.

\section{Methods and Materials}

This analysis is concentrating on Pakistan as a postcolonial state who is still facing issues due to its colonial legacy and still going through the pangs of neo-colonialism or the modern-day word i.e. imperialism. It is important to investigate various aspects of colonial discourse and postcolonial as a theory to establish well defined benchmarks which would work as touchstone for creative response from Pakistani writers. For the analysis, an eclectic approach would be used where I will be using interpretation combing with contextual analysis within the parameters of the research questions to elaborate on the themes and concepts propounded by Edward Said and Homi K Bhabha and highlight the issue of representation in the selected novels. As discussed above that post-colonialism analyses the relationship between colonizers and colonized during colonialism, after colonialism and sometimes refers to the period before colonialism. Therefore, different key terms have been coined to show different contexts. These terms are called post-colonial key terms which have different meaning, sometimes contemplating affiliation with colonizers or imperialists and sometimes rejecting them. Edward Said in his book Orientalism (1978) establishes a connection between the status of the indigenous people and the colonizers and establishes an argument where the issue of representation of the East has been highlighted. The colonized, according to the West, cannot represent themselves. So, it is their moral responsibility or to put it in Kipling's term White Man's Burden (1889) to make them civilize. To achieve their goal, the west started to colonize various parts of the world. Said challenges these notions of representation. Besides, Homi K Bhabha also gives certain concepts/terms in this context. These terms include appropriation, abrogation, hybridity, identity, diaspora, mimicry, essentialism, ambivalence, alterity, colonial education, ethnicity, hybridity, hegemony, mapping, metanarrative, magical realism and so many other key terms which play a vital role in the postcolonial studies. The current research has been undertaken with the same intention to highlight the different key terms and the post-colonial perspective through an eclectic approach, explicit in the Sikandar by M. Salahuddin Khan (2012). 


\section{Analysis and Discussion}

To start with, the title of the novel is of paramount significance. It is a nominal title which is named after the key figure or the protagonist in the narrative. Characters are, therefore, identified/explained through their names. Proper names are permeated and instilled with some linguistic, semiotic, or semantic significance which defines their roles in a narrative or any other piece of art. Writers, therefore, make full use of this onymic framework for transmitting their desired messages through the names in their novels. In addition, how the writers use different tools to this end. Since a name is always encoded with subliminal messages, it is the duty of a researcher to decode these messages contained in a name or title. It is therefore an essential element and becomes imperative for the understanding of overall message and impact of a narrative. Proper names symbolize identity and reference and it is this referential character of the proper names that needs a deeper look and insight to peep into the mind and soul of a writer and get what (s)he wants to convey.

Sikandar is also a proper name and the writer has consciously used it to convey leitmotifs which have been depicted in the narrative. As mentioned earlier, culture has become one of the shades of modern colonialism i.e., imperialism. Here, in this novel, the writer intends to bring into limelight an understanding of a culture. In doing so, he tries to convey the idea that every culture is a part of humanity, and therefore humanity becomes important as compared to nationalities, or regional superiorities. For the author, humanity becomes more important as compared to a race or culture. He has highlighted this theme in the preface to his novel (2010) by saying, "the story's setting in Afghanistan, Pakistan, and the USA is secondary to its core focus being that of an examination of human nature and behaviour across the boundaries between cultures". This is how humanity gets more value by showing mutual respect and dignity to each other for the sole reason of maintaining peace and prosperity across the globe. The narrative challenges the role of stereotyping which certainly creates doubts and suspicions among individuals and nations. Thousands of men, women, and children in the world find themselves in trouble everyday irrespective of their religion, culture, language, territorial boundaries, or race. Sikandar depicts realistic characters based on the true representation from Afghanistan, Pakistan, and USA to understand and appreciate and to have knowledge of the indigenous cultures and traditions before giving a final judgment about any.

Whatever the author claims, the plot of the novel confirms it. The story has been told through fascinating and credible characters. Furthermore, an underlying motif of a singular community adds value to the story. In understanding what the author claims in the preface, understanding of the setting of the novel gets significance. Setting is the physical location for the incidents happening. If it is realistic, it adds value to what the author stipulates. Since the writer has a natural inclination towards heavenly beauty, his protagonist always finds means to display it. This quest for exquisiteness in terms of beauty has been clearly manifested through the ultimate beauty of snow-white peaks of Spin Ghar and Hindu Kush to the "tranquil humility" like the Isle of Skye. It is easy to infer here that there are certain structural similarities between the landscapes. As a result, there should not be any hostility in human nature as well. It is therefore important to understand that all human beings share a single humanity. The writer stresses that the readers must look for respect and integrity in diversity. 
However, in the narrative it has not been so and that is also due to the American behaviour. Since the story has been written in the backdrop of 9/11, the character of the protagonist and the theme are interrelated. Sikandar stays the same character in body and soul as he was before the catastrophic tragedy of 9/11. However, the fact is that his identity and personality has been labelled as a stereotype for extremism and terrorism after the tragic incident. It looks, to the hero of the novel, a revival of the colonial period which divulged the difference between the self and the other i.e., the colonizers and the colonized. Once again, it becomes a cause of disagreement between the two nations and the author is stressing the importance of humanity not of the polarized worlds (Riaz et al., 2017). In this context Edward Said (1993) notion of the orient cannot be ignored. He remarks that the Orient is Occident's "cultural contestant and one of the deepest and most recurring images of the other." Spivak (1988), Landry (1996), and Loomba (1998) are also expressing their concerns in terms of representation of the marginalized. Similarly, Williams et al. (1993) also express the dilemma of colonialism.

The writer is depicting the character of Sikandar not being as a fanatic or extremist, rather, a very normal human being as he was before the incident. Associating the protagonists with mujahidin, it can be easily assumed that he along with his friends and comrades is a kind of extremist. But it is not true; he is not a one-dimensional individual and character. The writer depicts the human nature of his characters and their struggle and feelings and emotions behind the war. That is the one of the reasons among others that the protagonists and his friends should not be labelled as stereotypes for extremism and fanaticism. The writer has a very balanced approach in portraying the character of Sikandar. He neither glamorizes the life and struggle of the warriors like the historical figure of Alexander the great nor to gather sympathy for the hero or his friends. Therefore, the title of the novel has greater importance in bringing about the intended motif of the author i.e. respect and integrity for human beings across cultural boundaries.

\section{Conclusion}

Sikandar is an apt example of how imperialism has extended its influence over the former colonies and their inhabitant. The character of Sikandar has been portrayed through a postcolonial lens. Since this novel has been written in the backdrop of 9/11, the writer has shown the character of the protagonist as treated by the American i.e., as a stereotype. However, the character of Sikandar stays the same in body and spirit even after the catastrophic attacks and stays loyal to his nature towards America. His character is a balanced character because he is out of the clutches of geographical boundaries. He believes in humanity and not racism or any ethnic affiliation. As discussed by the author himself in his preface to the novel, it is humanity which is of value not the regional or ethnic loyalties. However, the problem of representation is still there in the novel. However, the imperialistic representation of the hero is still in the novel and Sikandar, in this process, has been marginalized. The writer, on the other hand, is trying to explain and highlight that for Sikandar humanity is of more value irrespective of its race, culture, religion, or ethnicity. The issue of representation is a core concept in the novel due to the fact the way the Americans are treating the protagonist. The tragedy of 9/11 was catastrophic; however, not every individual having Islam as his religion could be blamed for it. Islam and the Muslims are against any kind of terrorism. Due to certain individuals or their attacks could not be stereotyped for the actions of all 
Muslims. The author in his novel, Sikandar, gives importance to the humanity irrespective of its creed, colour, or caste. However, the story also shows how the character of the protagonist has been stereotyped.

\section{References}

Ashcroft, B., Griffiths, G., \& Tiffin, H. (1998). Postcolonial studies: Key concepts. London: Routledge.

Ashcroft, B., Griffiths, G., \&Tiffin, H. (1989). The empire writes back. London: Routledge.

Ahmed, A. S. (1997). Jinnah, Pakistan, and Islamic identity. The search for Saladin. Karachi: Oxford University Press.

Ali, A. (1984). Twilight in Delhi. Pakistan: Oxford University Press.

Bassnet, S., \& Trivedi, H. (1999). Postcolonial translation, theory and practice. London: Routledge. (Digital Printing, 2002.)

Bhabha, H. K. (1994). The location of culture. London: Routledge.

Hall, S. (1997). The work of representation. In Representation: Cultural Representations and Signifying Practices, ed. Stuart Hall, 13-74. London, Sage Publishing.

Said, E. W. (1993). Culture and imperialism. New York: Vintage Books.

Said, E. W. (1978). Orientalism. New York: Vintage Books.

Spivak, G. C. (1988). Can the subaltern speak? In Marxism and the Interpretation of Culture, (ed.), Cary.

Spivak, G. C. (1988). In other world. London: Routledge.

Landry, D., \& Maclean, G. (eds.) (1996). The Spivak reader. London: Routledge

Loomba, A. (1998). Colonialism/Postcolonialism. London: Routledge.

Mukherjee, M. (1971). The twice born fiction. New Delhi: Heinemann.

Rahman, T. (1991). A history of Pakistani literature in English. Pakistan: Vanguard Books.

Riaz, W., Malik, S., \& Rahman, B. (2017). Quest for identity in Bapsi Sidhwa's an American Brat: A postcolonial perspective. Liberal Arts and Social Sciences International Journal (LASSIJ), 1(1), 32-40.

Shamsie, M. (ed). (1997). A dragonfly in the sun. An anthology of Pakistani writings in English. Karachi: Oxford University Press.

Talbot, I. (1996). Freedom's cry. Karachi: Pakistan Oxford University Press.

Williams, P., \& Chrisman, L. (eds.). (1993). Colonial discourse and post-colonial theory. London: Harvester Wheatsheaf. 